\title{
Dancing Earth: The Continuum of Dance as Embodiment of Inter-Tribal Knowledge
}

(Transcript of the paper as delivered, with special thanks to Dr. Karen Barbour and to Dr. Peter Cleave for editing)

Rulan began with a prophecy song and then commenced her talk by referring to it;

This is a prophecy song that was shared with me by Edna Manitowabin of the Anishnaabeg First Nation. She has since asked for women to whom she has taught this song to consider sharing at this time, perhaps because this is the time of prophecy. The deep symbolism of the words cannot be adequately conveyed in English, but essentially are saying, "awaken people, it's time to get up".

That's where we're at, at this time. It's time for awakening, the time of prophecies....

For this important journey of DANCING EARTH to come here to Aotearoa, we carry with us words and teachings and songs from many intertribal Nations that we collectively represent. And we carry many philosophies in the potent form of language that is dance, to honor and to acknowledge with gratitude this invitation. One of the first gifts I was given by one of my grandmothers was a medicine wheel made of deerskin. It is a circle, with connecting lines between their four points cardinal points. When you see a medicine wheel it's a flat dimensional representative of a spherical multidimensional worldview, so at first you see it as identifying four appear at a major dance festival in Aotearoa; she gives love and appreciation to her Maori and New Zealander colleagues for ongoing relationships that strengthen global Indignity through the powerful art of dance 
points (and later you view the circle as a sphere and those four points become many). So, there are character qualities associated with those four points, these were described to me, as humility, honesty, courage and generosity and these are qualities I am asked to bring into this world and on this journey.

Humility is a word that in English is sort of awkward but here it applies to being able to be humble, be appreciative, be thankful. So I have to acknowledge the absolutely wonderful, tireless, wonderful work that Jenny, and Tane and Merenia have done from the Kowhiti festival to open up their vision to bring in this global indigenous awareness, it means a lot to us. Thanks also to the US Embassy - we couldn't have managed the travel without them and it somehow turned around our relationship around the US government, for Dancing Earth to have been chosen as representatives, and supported for such an honor! (laughs)

And also to my long, long term colleagues Terri Ripeka Crawford and Tracey Marama Lloydd. I first met them in Canada at the Banff Centre for the Arts under the leadership of Marrie Mumford, in a major Opera production directed by Alejandro Ronceria and Sadie Buck. At the time, they said you need to bring your work out to New Zealand, and throughout these twelve years with much love they cultivated that dream. Then Jack Gray brought his special sparkle and confidence to say, "yes we can do it".

So I say thanks and I also say thanks to the Ngati Poneke people, the original people of this land for their songs and dances that have kept this land alive for many generations and without which we wouldn't be here today.

So what I want to bring up is (Toka Wiya) - one of the names I carry that isn't often shared with many people - which means first woman. Something that is first is also something that can be a little bit strange, different, something that's an originator and I think that what I'm birthing here into New Aotearoa: it's the first of many things. It's the first time in the 
collective memories of the people here and our continent for a dance company to be invited from New Mexico, for a native dance company to come from North America, to be invited to present our work at the Opera House and a major festival in Aotearoa.

So we believe that this is a real first that signs up with prophecies, evidencing the importance for indigenous people to be able to connect with each other, on behalf of every one and of the land, and the water, and our ancestors.

So let me show you some images. [Shows image].

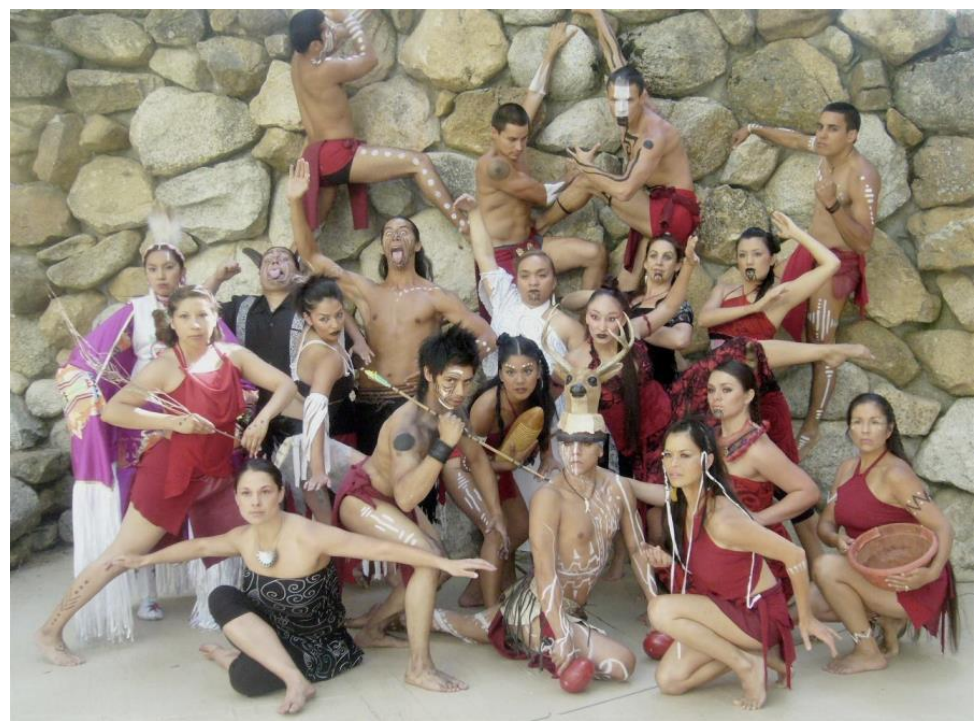

Photo: Anthony Thosh Collins for Dancing Earth

Pictured: Dancing Earth with Korou Productions and additional guest multi-disciplinary artists from First Nations of Mexico and Canada

This is actually an image from 2007 in which Dancing Earth was joined by my Maori sisters and artists that assembled under the name of Korou productions, along with Indigenous artists from Mexico, Brazil, El Salvador and 
Canada that, as well as my company. So this is one of the seeds that was planted.

I was speaking of talked about the four principles, humility and now honesty. Honesty, so ever since the equinox (our fall October equinox and your spring equinox, September 21st ) I have been meeting with different elders in order to prepare myself for speaking, and the idea of honesty was actually described to me as straight talking. So to be able to talk with you the way I would talk to my friends, the way I would, so not any kind of fancy talking. I was worried about trying to be academic. I'm smart, my body's smart, my mind's smart but I wanted to .... , you know, I was worried about this kind of languaging and they said, you know, "that the truth should be spoken the same way everywhere".

So that's why I'm choosing to resist reading from a prepared paper. I was also told that if you've been asked to speak and you need to be reading constantly from a paper then you have no business speaking [laughs]. You need to rely on your instinct and your, your belief in the knowledge that has been shared with you throughout your life to be able to speak and take in the energy of the room and address the issues at hand. So I'm, I'm doing my best to do that.

The next quality: courage. Courage can be defined as being able to act with love and I know there was a lot of love that came through bringing this festival together. We have been so embraced by the friends that are helping keeping us fed - with true Maori hospitality!- and that's really a metaphor for what it takes to keep our dance skill going. We are being deeply nourished by our hosts - and previously by our mentors and elders and ancestors - so that we can be strong healthy and bright to attract in the people and energies who then can be transformed by our work.

Next quality: Generosity, I also associate that with inclusion and reciprocity and kindness.

So these are all themes that I'll be addressing and talking about in the context of my work and my work specifically so 
that you can better understand what it is that we are bringing into the bowl so that we understand what it is that we are all bringing to the world.

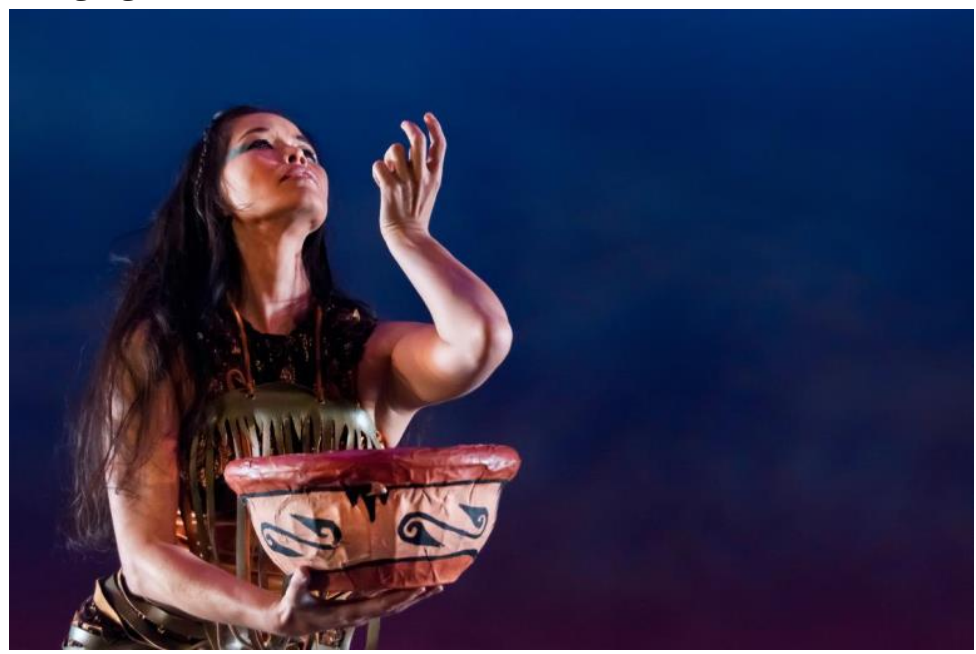

Photo: Paulo T Photography for Dancing Earth Pictured: Rulan Tangen

So in terms of purpose, why is this important? Louis Riel was a leader from Canada and about 100 years ago he said, "for my people will sleep for 100 years, and when they wake up it will be the artists that are warriors". So this is the importance of why we are all here now as partners for supporting the arts because this is the way our culture will continue and go forward and adapt with the times and find what is still true for the times that we have at hand.

Our indigenous dances are of course rooted in our culture and our cultures, these are in Nevada and in South America, so both in North and South America.

They predate the Barren State Theory by tens of thousands of years and often scientists don't know where to place this knowledge. It's the same with our creation stories they are considered beautiful myths, stories and then recently 
DNA tests have now shown, "oh NOW we understand that people have come from the stars, that everything on earth is made from the carbon from dying stars".

We KNEW that, we knew that in our stories, carried in our bones and blood and social practices and ceremonies of relationship with all beings as relatives, and with the skyworld. We knew that through our stories which are easier to remember because of the way the stories were told through words and song and dance and food sharing. And this is just one creation story and each Nation carries a different creation story - maybe from underground, or from water, or from rock, or from a four legged or winged parent - so that each is responsible for remembering a different crucial part of how to live on earth. There are 566 acknowledged First Nations in what is now called the United States and many more that are not acknowledged, and originally almost as many languages. Each one has a creation story, each one of these creation stories holds knowledge that helps us understand the world.

So our dance in theatre has a root of functional ritual, it is the songs and dances that for at least many tens of thousands of years have taken us through courtship, through death, through puberty. There are songs that bring us through these rites of passage, and dances that remind us of relationship to the four-legged, to hunting and the treaties of balance made, with some making sacrifices so that others may live. 


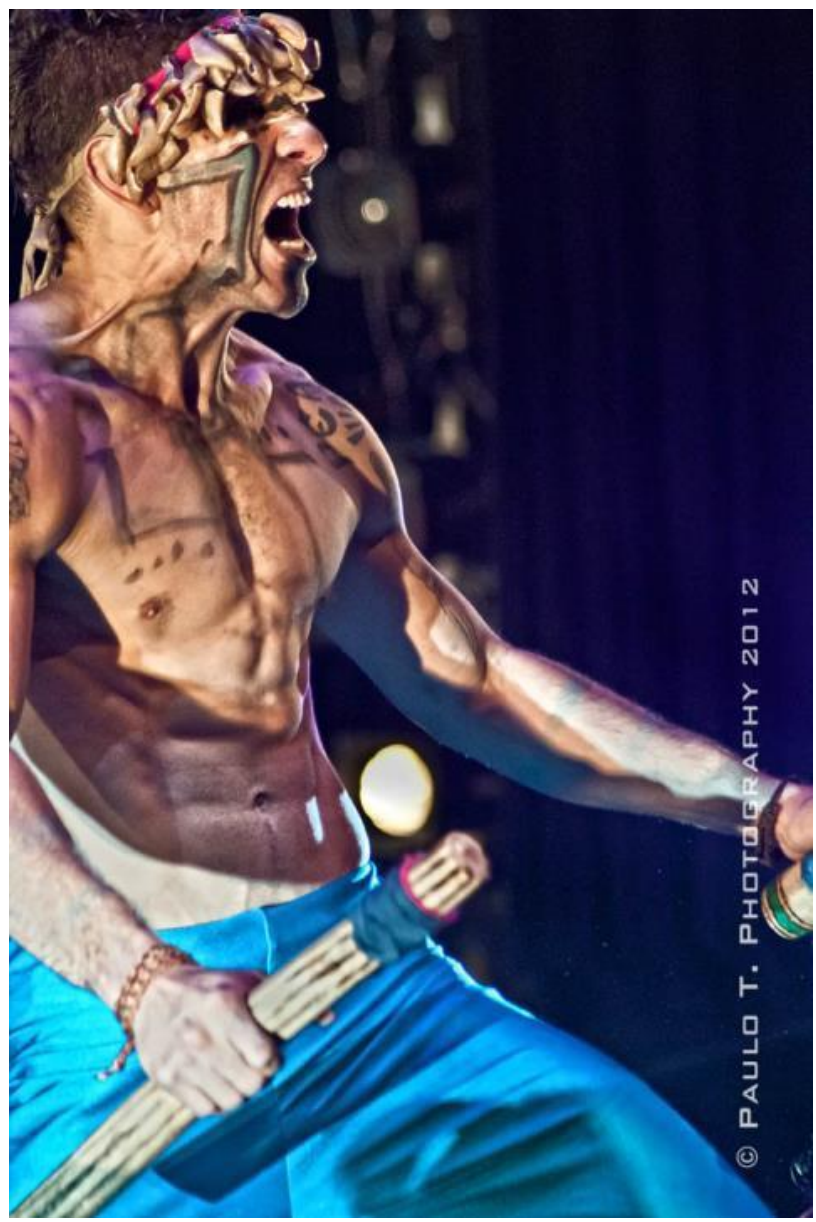

Photo: Paulo T Photography for Dancing Earth Pictured: Xeric Meraz

So this is one of our images that bring back in these ideas of the Shamans, the medicine people. And, interestingly enough when we cast these with our company we find that we're not just portraying characters, that often when I'm casting someone it turns out that they actually are from a line 
of healers, or of medicine carriers, when I cast them in that given role.

So it's a very interesting thing about our company that we're not portraying something outside of ourselves .We actually are presenting on stage who we really are using that quantum physics idea of past, present and future overlapping all at the same time. I think that's something that is harnessed in indigenous people and we're constantly aware of.

So these are some of the four-leggeds and birds some of the ancient images that we use [shows images]. In this case the wings are made out of basically trash, recycled material. We're working with recycled and repurposed materials be that our ancestral knowledge and also things that have been trashed and thrown away in the corners.

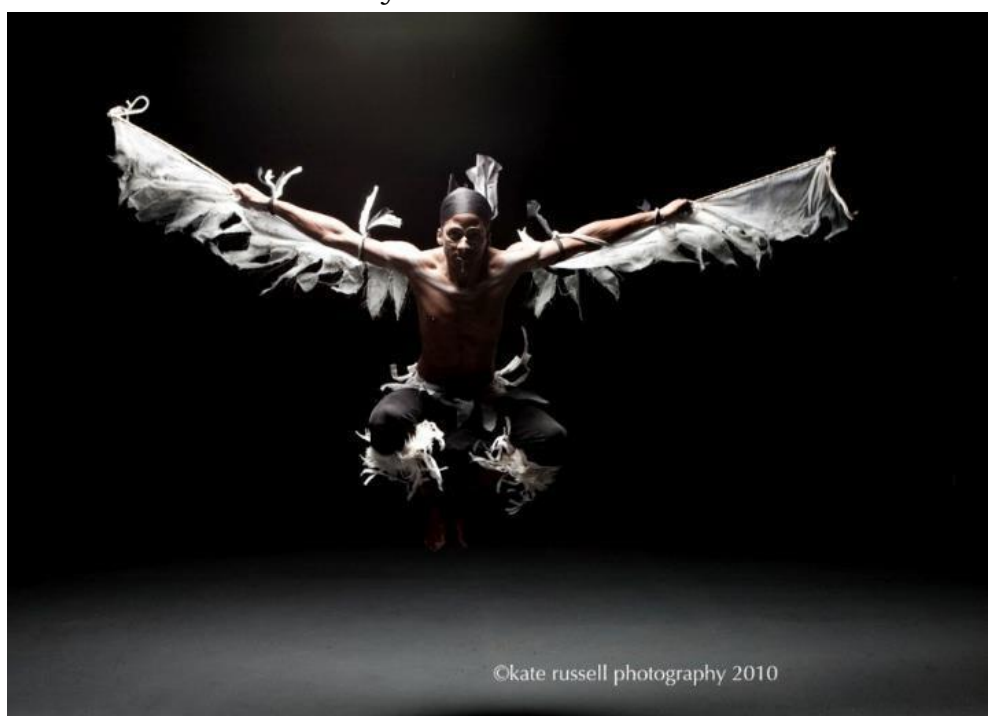

\section{Photo: Kate Russell for Dancing Earth Pictured: Deollo Johnson}

One of our first exercises is rolling on the floor and what I describe is, "imagine that you dissolved into the things that are in the corner of the room - in the dust and the fingernails 
and the bones ... and the people and the languages that have been cast aside and imagine if you could roll and use this spiral of life in order to bring those back to life".

So animism is a really important theme. I was talking about how coming from the stars we are all related and that I feel the life force that is in everything. So when we are dancing, we could dance as vegetables, we dance as animals, we dance as four-leggeds and occasionally we dance as humans. But part of it is for us to be able to know our place in the world by understanding the movements and the life force and the energy of these different relatives of ours.

In addition to functional ritual there's a long tradition of very stylised ritual that is very elaborate with ancient Indigenous precedents for some very sophisticated elements of theater. I think there might be a misconception about ancient Native dances as being happening very simply, maybe around a fire, with very powerful energetic transformations but very simple. But I want to point out, that in the West Coast of the Americas as well as in Central America there's a long tradition of arts that we, if we were to see them now we would think they were in a circus: stilting and voladores who were dancers that were dancing on long ropes, basically a prelude to aerial dance. Those were long traditions, pre-Columbian traditions in South America and on the West Coast they had long houses, with long logs, that were burnt out in the middle and had very sophisticated lighting. Their works included: oratory, they had song and elaborate regalia that in a theatre context would be called costumes, they had dance, they had canoes and they had masks - all in one production that could last for days. It's comparable to what was happening many hundreds of years later in the European courts of the Renaissance with ornate theatrical ballet operas and feasts events that lasted several days.

So we come from this very rich tradition, everything that we're trying to do in contemporary theatre that is 
interdisciplinary already exists actually, it already existed with our people many years ago.

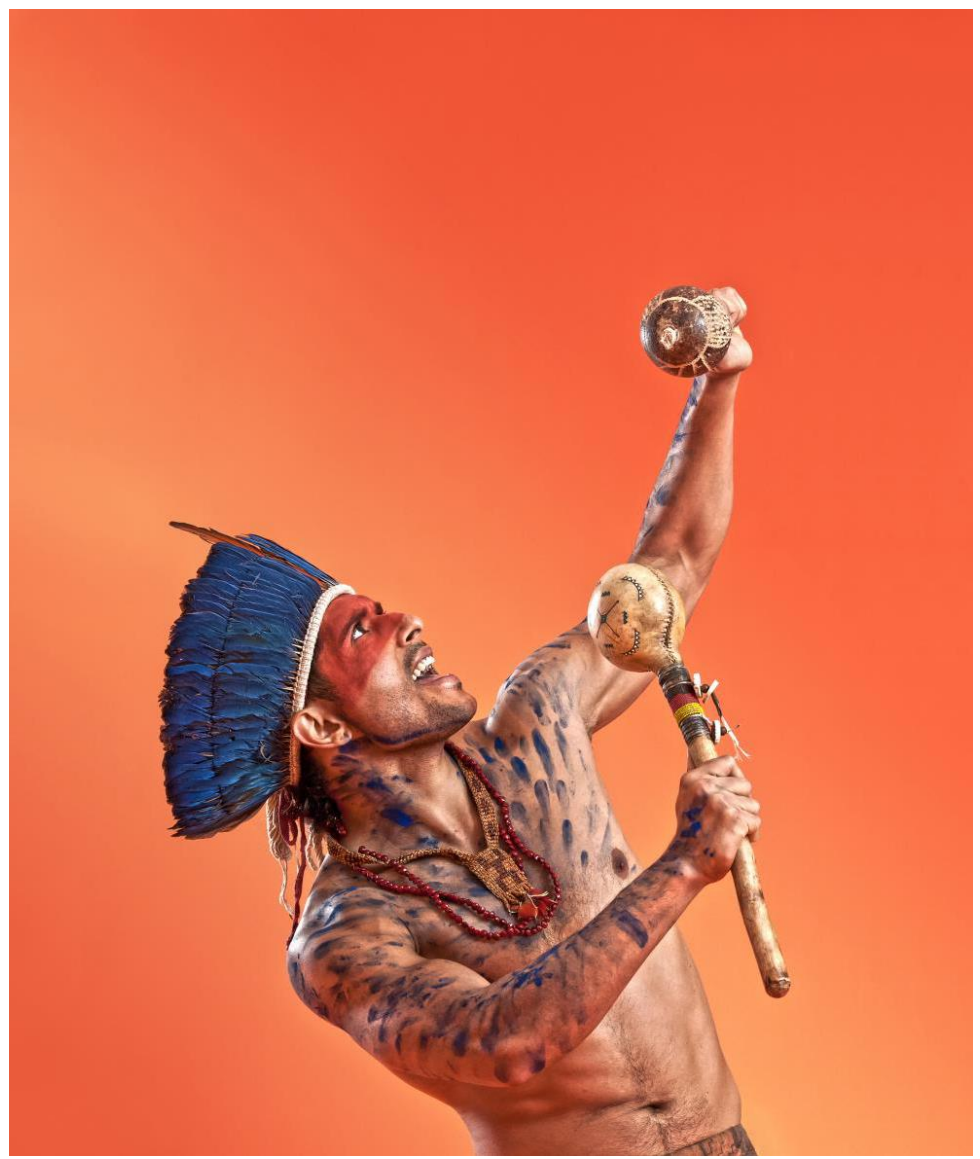

Photo: Paulo T Photography for Dancing Earth Pictured: Quetzal Guerrero

This one [shows image] is an original founding member of Dancing Earth; you will see him onstage at Kowhiti as dancer and musician. He designs some of the body paint for us because of his background as a painter: an example of how 
many of the dancers are also interdisciplinary artists, musicians, educators, culture carriers, water warriors and humanists.

So moving from the sort of general landscape of the richness that we have drawn, I have some specific points in history that I think really informed the dance in America. One is the ghost dance of the 1890s. So in the late 1800s things were not going well, not going well. By that time the east coast had really been the frontlines for a couple of years and plains people were now starting to feel the full effects of smallpox, of battles, and so in Nevada - one of those places where there are bones that were thirty thousand years old thus challenging the Bering Strait theory - there was prophet named Wovoka and he had a dream vision. His dream vision was about all the different tribes uniting and using song and dance to bring back the days of the buffalo and send back everyone to where they came from so they could live their Indian ways again and what they were recommended to do was to try to let go of the things that they'd been given, the cloth, the metal, the kettles and this kind of thing but by that time they weren't allowed to be hunting the animals so what they chose was the simplest cloth they could find. It was basically a muslin because it almost looked like buckskin and this prophecy was so, the message was so magnetising to people.

It was one of the first examples of an inter-tribal unity that was happening. Everywhere that he went there would be people that wanted to dance this dance. So this was regardless of different geographies and different languages. There was quite a lot of trade but there was more interest in those times in being able to retain your differences, but with this Wovoka prophecy its seen as we're facing, you know, an onslaught and it's time to meet that. So this simple dance, this round dance circular step, this ghost dance was being danced in South Dakota in the summer of 1890 and these women and these children while they were dancing were the ones who were massacred. So I don't know if everyone knows that these were 
people that were dancing at that time. But this is when it was said when the sacred hoop was broken. When you could go to the most sacred and most essential of our beliefs, of our worldview. They believed it was the dance and song that could bring about transformation - that's the core belief to remember about those brave people, so that in losing their lives those beliefs are not lost - that's what matters.

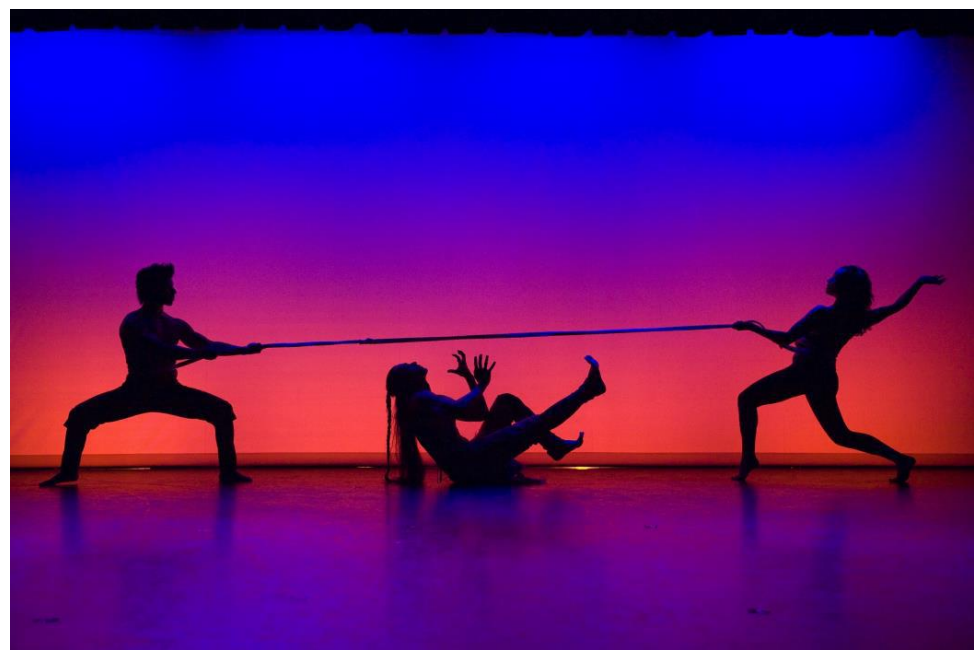

Photo: AMT Productions for Dancing Earth

Pictured L to R: Edgar Soto Garcia, Kalani Queypo and Serena Rascon

Now we hope for our indigenous contemporary dance to be like the ghost dance in that it can rally people from many background and we hope for a better ending.

I think what's significant about it, I put it in this bowl that I'm bringing to you is that it's a dance of resistance, it's a dance of solidarity and it's a dance that embodies a new reality. This is very key to teachings that have been shared with me about what to share with the outside world and, for example, for a lot of elders they feel that there is already too much of a romanticised fantasy about Native people, or on the other hand over-emphasis on the bad conditions and what 
they have caused for Native peoples. There's more details to it but we want to show what we were and where we want to get to again, it's like a past, present and future overlap.

So this idea of being able to birth hope and being able to birth in a new reality - using the imagination - this is where the artist warrior part comes in - using the imagination to be able to put in front of people a reality we live out while we're on stage: the powerful ancestral wisdom and then the deep challenges to our lifeways, and the purification and renewal that we are envisioning - we open our body minds hearts and spirits to invite all of this to permeate through.

Similar to that came from the Buffalo Bill Wild West Show.

So after this massacre this was around that time when everyone had been placed on reservations, forbidden to hunt, forbidden to do the things that were the way of the native on the land. Then came the Buffalo Bill Wild West Show, which was basically these show business people coming to the reservation offering mostly men and some women: a job, a chance to travel - where they subsequently met European people who were not immediately trying to kill or criminalise them and the job was to wear regalia, ride horses, dance, sing , and to re-enact their war deeds ! So it was really the beginning of professionalizing of Native activities into theatrical entertainment format. It led to the dances becoming more and more virtuosic, eventually leading to what has become the dynamic male fancy dancing, and hoop dance. You can imagine what it felt like at that time...

It would take you to another land but the place where you were being appreciated - even if rather exotified - but at least more appreciated by the outside culture than you were at home. And for some of you that do that kind of touring, you know what it's like, to land somewhere and be welcomed; whereas at home, there might still be prejudice. It happens for us all the time in the different regions we tour in the US or Canada. "Oh yeah, we like your Indians, you guys are great! The Indians here are, they're no good, but you guys are great", 
crazy but true! So these performance opportunities were a form of freedom, and that's something that I've put into my basket: the idea of re-enacting and theatricalizing of lifestyle, some of which may have had roots in ritual. That is what we were able to make of that Buffalo Bill Wild West Show opportunity.

Soon after that was the suffragette movement, the push towards the right to vote, as a manifestation of the emancipation of women in the United States.

Through the 1800s, Euro-American women in the North East found themselves visiting with Iroquois and Algonquin women who were their neighbors.

Earlier than that, the principles of Iroquois confederacy inspired the constitution written by Thomas Jefferson. I don't know if they gave it or he borrowed it or took it without permission, but he was smart enough to understand it represented an entirely different form of governance that had not existed in Europe. No-one had yet experienced leadership where everyone was given a voice. So Thomas Jefferson wrote a version of those principles so all citizens, meaning all white men, would have that right. 


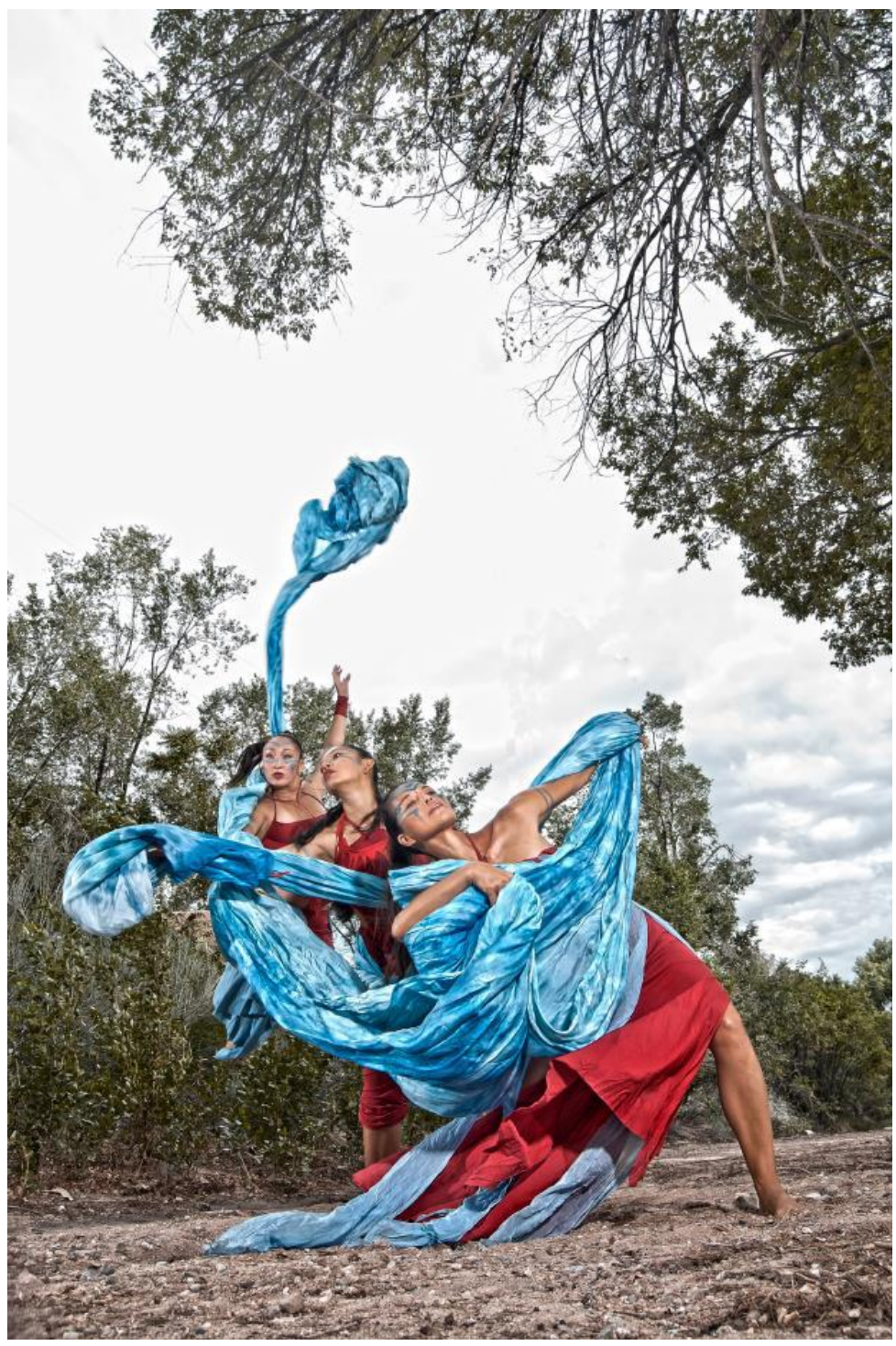

Photo: Paulo T Photography for Dancing Earth

Pictured L to R: Nichole Salazar, Anne Pesata and Rulan Tangen

Te Kaharoa, vol. 8, Special Edition, the Kowhiti Atarau collection, 2015, ISSN 1178-6035 
Now the women that were visiting with Iroquois and Algonquin women found that even the women had a voice. In fact the women were actually running the show. They were giving instructions, the harvest of corn or of maple syrup belonged to them, they were the ultimate decision makers in the families and in governance. These European women, they had never seen women who were not only living as respected equals, but even were leaders. They saw in them freedom and independence, even in what they wore, leggings or comfortable skirts with loose tunics and these same women, inspired them to loosen the corsets and try loose fitting pants - bloomers, worn under dresses and a huge scandal in society.

So there's this idea of women's leadership, of acknowledging the matriarchy that, I take with me into my practice

I was a young dancer in ballet, modern dance, operas, powwow, what I wanted was to dance in a Native modern dance company. But it wasn't happening anywhere I could find out about (in the days before internet), or eventually I would find short projects, but I wanted to be doing it all the time.

So you know how it is with women, if you want it to happen, you make it happen yourself. You create, you give birth to it. And that's the message from this.

In World War Two when the men came back, in their absence the women joined the workforce and were in charge of the households and their own paychecks - Native women, non-Native women, it was happening for everyone. When the men came back there was a lot of celebration. There was still a ban on any sacred dances in the aftermath of the Ghost Dance, but there were powwows. Powwow comes from an Algonquin word meaning - to gather. For aeons, tribal Nations would gather at certain sites at certain times of year, to trade, feast, court, and always dance and sing. So powwow dances could be held as social dances, any sacred or ceremonial roots had to be quietly hidden so that they could continue to exist. 
That happened in other areas such as the southwest, with religious dances being preserved by holding them in honor of a Christian saint, on church grounds. There was nothing that was not spiritual, all the culture was connected and intertwined. That ban was not uplifted until 1979-1980, until then nothing that had any religious connotations could be practiced in public. So anything either had to be done secretly, sacredly, underneath, literally underground. Or, altered with the sacred part alluded to or perhaps lifted into an almost invisible realm. 


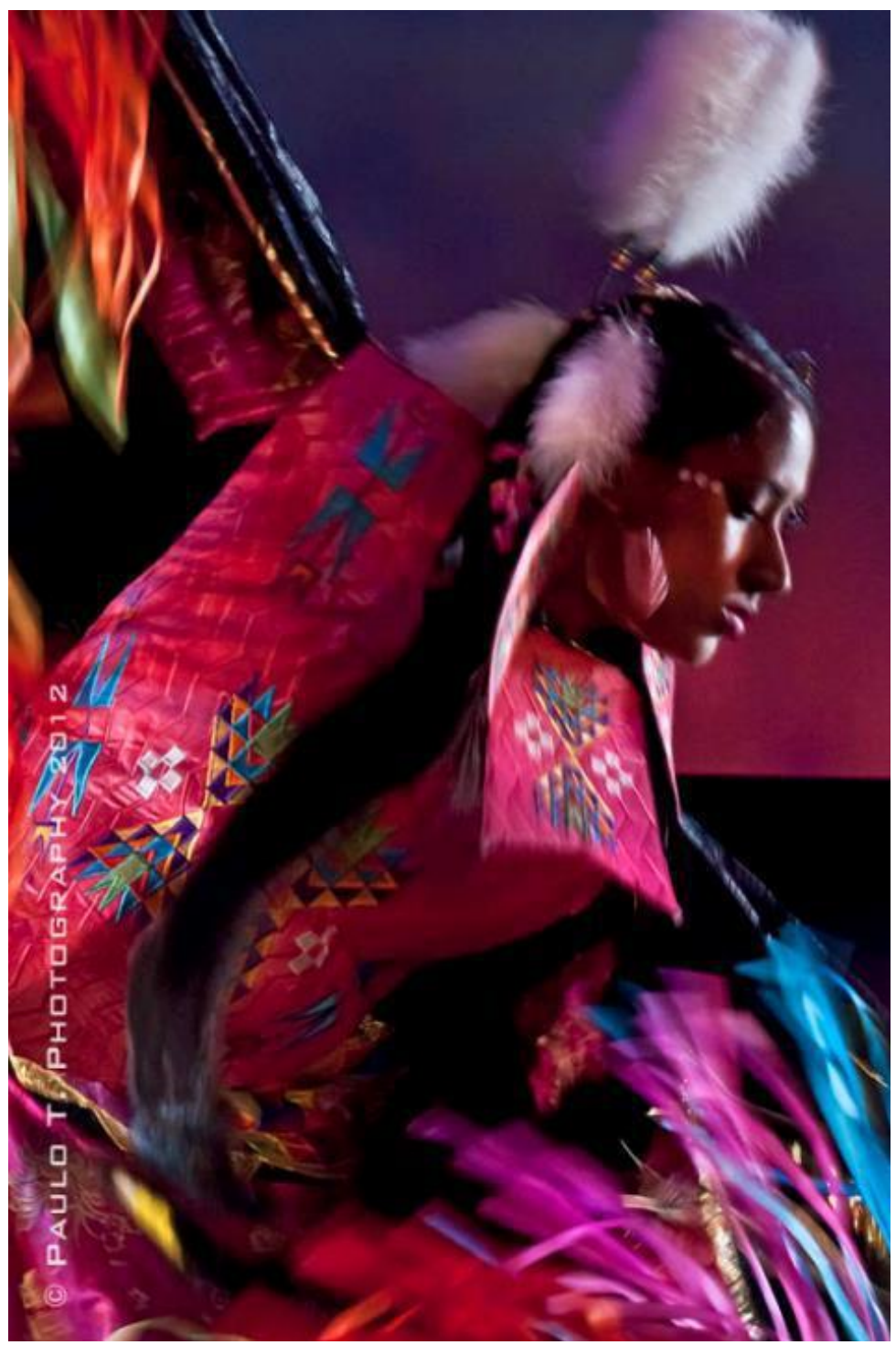

Photo: Paulo T Photography for Dancing Earth Pictured: Erika Archer

Te Kaharoa, vol. 8, SPECIAL EDITION, the Kowhiti Atarau collection, 2015, ISSN 1178-6035 
Some of the powwow dances might have come from older dances with sacred lineages but those stories were silenced and what we have left are movements. And by repeating and renewing these movements, we would start to understand through our bones what their meanings are.

And anyway the Buffalo Bill Wild West Show encouraged the virtuosic creative development of the men's dances - they were lifting up their feet more, a lot of action and expression and life force. So at the end of WW2 the women said, "well, we can do that too"! Previous to that, women's dances were very simple refined elegant movements. Well, basically two movements, this and that [demonstrates movements, bending and straightening of knees]. Very simple, but profound. You try doing this from morning all the way through the night, you find you actually connect to the pulse of the universe. It's an expression of quantum physics - to every action there is an equal and opposite reaction, so in bending down you are reaching up, and in straightening and lengthening the leg you are sending energy down into the earth. That's basically everything you need to know about dance! So the women already had this powerful dance but a few of them decided they were going to start doing these fancy dances like the men. This wasn't too long ago, maybe the fifties or sixties, when these ladies were trying this form, wearing the men's clothing. And, what was the reaction? They had apples and oranges thrown at them because they were not acting, they were not conducting themselves in the manner deemed appropriate for women. So they changed their garments and put the traditional women's attire of a dress, with a shawl over the shoulders and kept doing that energetic dance. And, the truth be told, fancy shawl dance for women is now considered something that's very, very respectable, honourable and desirable to do, the shawls look like bird or butterfly wings with long flying fringes that themselves are dancing. So I remember that because when you find yourself at the beginning of something, originating a new idea, trying 
something new, before it becomes accepted and maybe even honoured as a 'tradition' in less than one generation, we might have apples and oranges thrown at us. These women kept going, following their inspiration, their dream.

These days in powwows there something fun called the switch dance in which everybody switches outfits, so the women wear the men's outfits and the men wear the women's outfits and they all get to do that so, sometimes something that's looked down on becomes something everybody wants to do later.

Meanwhile, a lot of native men had fought in WW1 and WW2 and were heroes. In fact only recently did it come out that the Navajo code talkers would speak to each other in code and they were partially responsible for the war's victory. They were not allowed to ever discuss that until very recent years. So these high honours that they gained for the United States were not acknowledged, nor were they even able to vote.

So after those two wars the vote was not gained until the late fifties and sixties, tribe by tribe and state by state.

So around the time of Martin Luther King and the civil rights movement, Native people especially urban Native people became inspired to get some voice and visibility for themselves, at long last. It was really a time for American Indians to sort of reclaim political power. I look at San Francisco where my Mom is from, late '60s and early '70s. Many people had been relocated, through enforced relocation to cities far from the reservation, or sometimes by choice after being taken away from their families and placed in boarding schools, then returning home with no knowledge of language or the skills needed for community participation, so having no place. First they were put to reservations, then sometimes removed to other reservation areas very far from original lands, then relocated into cities. And they stayed there so they were urbanised people who had been in cities like San Francisco, Denver or Chicago for many generations. 
And these San Francisco urban Natives decided that they were going to make a stand. And what they set their sights on was an island that was a short boat or canoe ride from shore. It was called Alcatraz, and it had been a high security prison. And that was when they decided they would reclaim, as Native land. It was a powerful call, to be visible, acknowledged, to reclaim, to tell the true stories and let people know around the world know that American Indians (the term at the time, which changed soon after) still existed and what they and their ancestors had lived through. This was before internet or cell phones, before any of that and Native people came from all across the country to meet in San Francisco and Alcatraz. It was a wave of intertribal solidarity that activated people of so many First Nations, with hope and empowerment, similar to what the ill-fated Ghost Dance had done less than a century earlier.

And what's key to me about that moment is this idea of being able to reclaim your identity. So while people might have felt separated through urban living, people knew they were Native, no matter what, even with the internalised oppression based on what the government- issued certification which is the only legal way to claim Native heritage. Legal is less important to me than love for your people, and there is a lot of that aroha here in Aotearoa, and that's something I will gather in this basket!

So in this, in this melting pot of San Francisco during this period, people were able to say, "I'm being proud to be Native", and it brought out the Indigenous pride beyond borders, beyond governmental certification. 


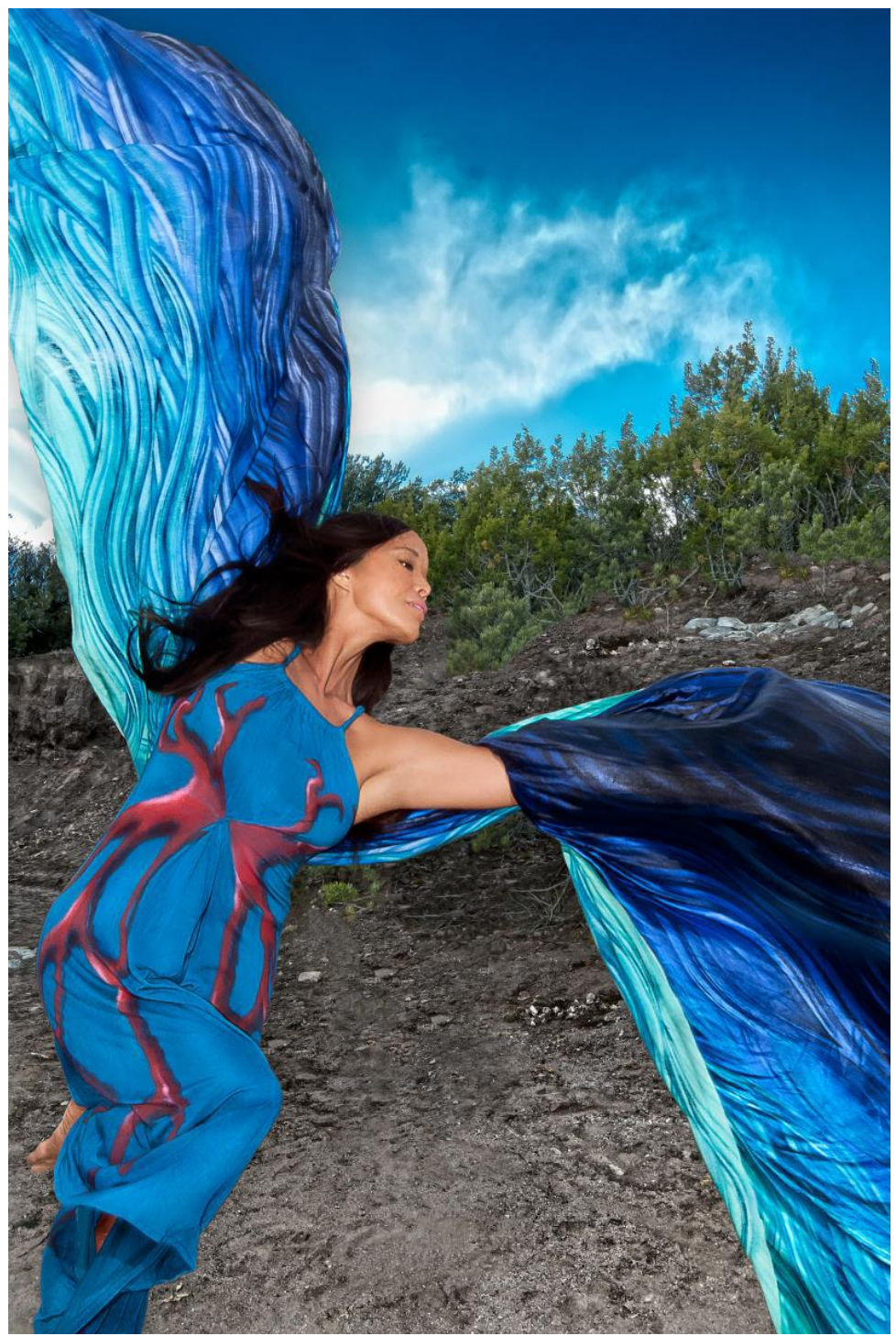

Photo: Paulo T Photography for Dancing Earth Pictured: Rulan Tangen

Te Kaharoa, vol. 8, Special Edition, the Kowhiti Atarau collection, 2015, ISSN $1178-6035$ 
To this day, I feel San Francisco is one of the most welcoming sites for Indigeneity: it's about community, not about false borders. In that era, these urban peoples were borrowing or sharing different symbols and words - a lot was shared by the Lakota. It was a way to exhibit solidarity, bearing in mind the huge diversity of tribal languages, and many of these peoples had survived boarding school education where their languages had been erased from them. So there was healing to do, filling gaps, borrowing of elements from others until people were empowered to uncover more of their own cultural heritage. These days there are those that look down on those aspects of that era as pan-Indianism, oh, they didn't even know they were they were just borrowing everyone's everything. You know what you do, if you don't have a coat, you borrow one until you grow your own fur [laughs]. But the important thing was the alliances that were built, the solidarity and socio-political strength and visibility, that empowered many people to be proud of who they were and this would lead to people recovering their own specific cultural knowledge, as well as growing cross country ties, relationship and understandings of other Native peoples.

So this is something that can happen in my company of Dancing Earth. Young people come in, they may have been adopted out, they don't even know who they are or where they are from and it's not their fault, their records were burned - so many sad stories of disconnection. So what we do is we share, we share, we give to the ones that have less so that they can have something to stand with, and the interesting thing is that through our physicality, the improvisations the we do, things will come up, knowledge will reveal itself through the body. 


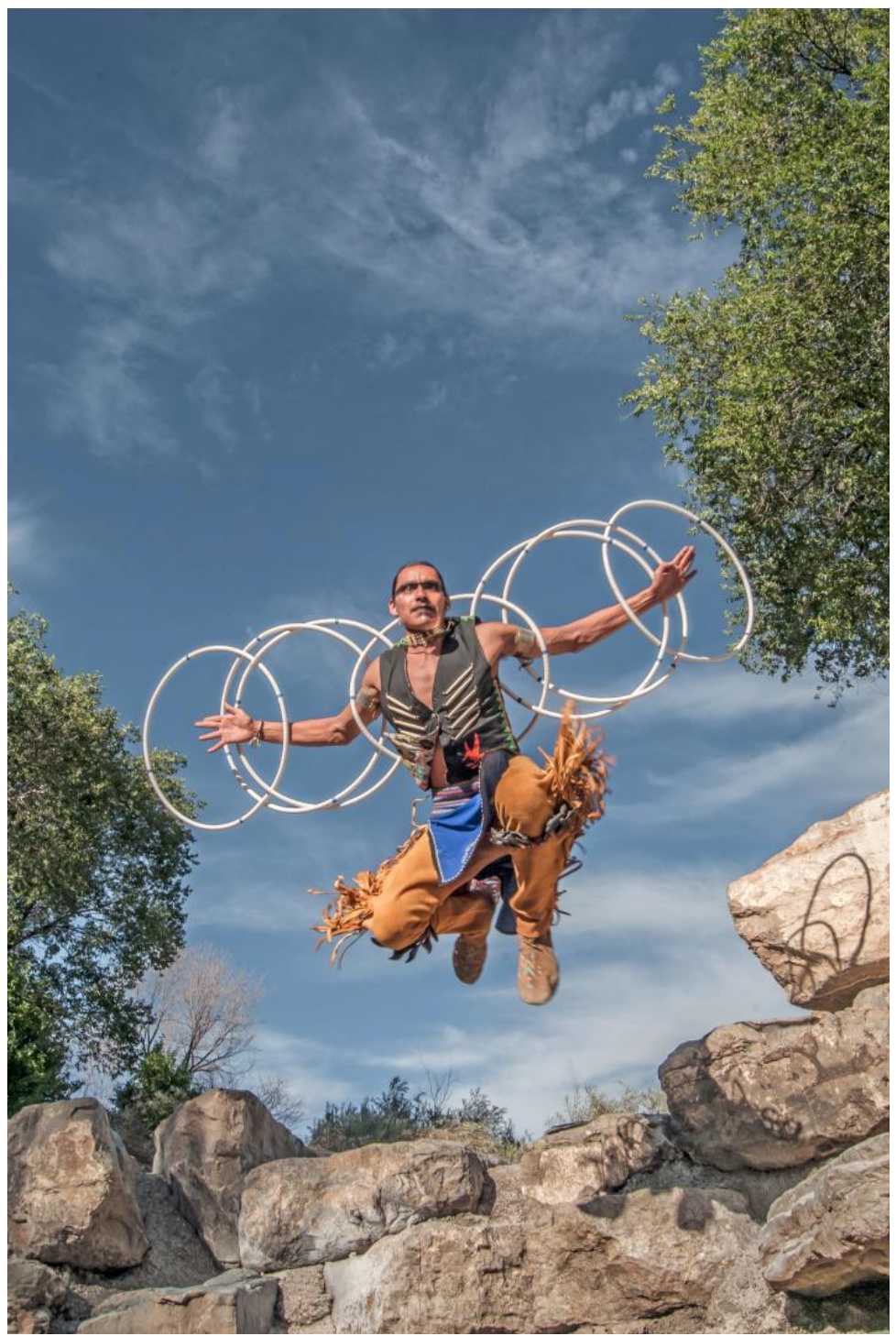

Photo: Paulo T Photography for Dancing Earth Pictured: Lumhe "Micco" Sampson

Te Kaharoa, vol. 8, Special Edition, the Kowhiti Atarau collection, 2015, ISSN 1178-6035 
We call it ancestral memory, or 'blood memory' from the brilliant Kiowa poet N Scott Momaday. There was a young dancer and in her improvisations there was a strong quality of water. I cast her in a water creation story. And, we find out much, much later that she's from the Yaqui people of the desert and one part their creation story has to do with the people coming out from of the water .

So this is what we talk about, our ancestral knowledge, our blood memory, this is what comes out of our dance and people say we're crazy artists imagining these things. But imagining reality is also reality. Besides that, there's also science that is just now catching up and telling us that inside your spine is your marrow, in your marrow is your DNA, in your DNA is the link back to mother's, mother's, mother's, mother's mother. We knew that as dancers and now we have the words of the science behind it but when you feel it, when you experience that truth, you know it's real, long before science catches up. This is true of all our stories, they are not myths, they contain very complex and specific information about our world and science is starting to make major discoveries that parallel small aspects of these stories. So the important thing is to remember these stories. Re-tell them, repeat them, renew them, sing them and dance them, forget the words but live them, be them ..

In about the 1970s there was a very famous television commercial and I'm not sure of the authenticity of it but as an image it's very strong. Basically people are driving in a car, they have fast food and they throw the trash out on the street and next to the street are, is a forest of trees and there's an Indian crying. It's a memorable image that was put forward by the environment movement and I just wanted to acknowledge that our native cultures hold the founding principles of the environmental movement, and the modern day permaculture movement.

I have a new work I'm researching and it's about seeds, plants and food, and I'm asking around about permaculture. 
The Native farmers they say, "permaculture, that's just what we do, that's just the way we do it, we don't even call it farming or call it gardening, it's just what we do. But when people come and try to learn from us and write a book about us, then give lecture about it, then they call it permaculture".

So I'm just putting that environmental consciousness, into my basket.

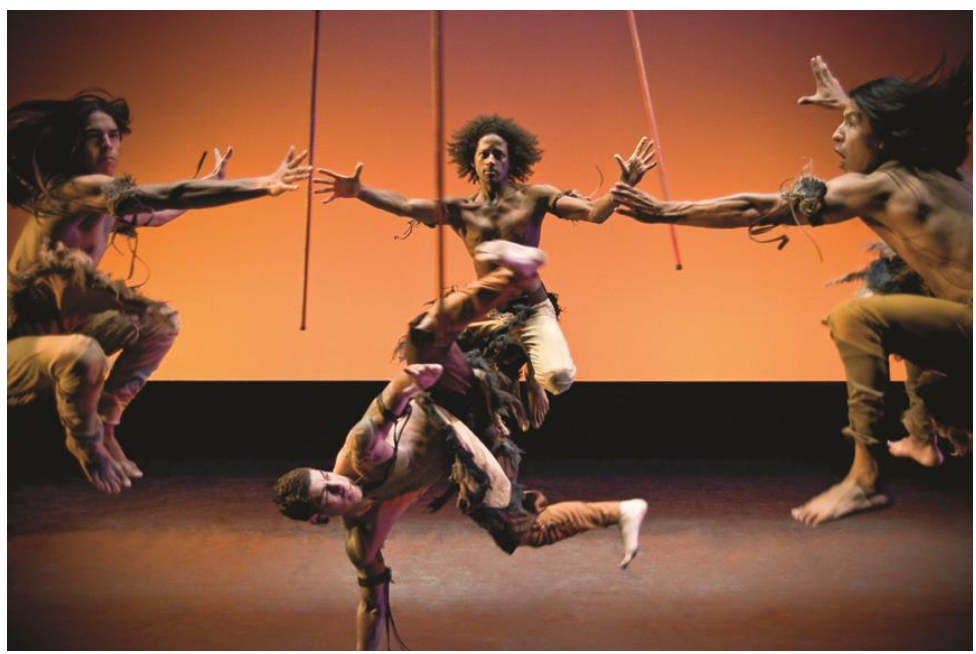

Photo: Paulo T Photography for Dancing Earth

Pictured L to R: Ehren Kee Natay, Deollo Johnson, Xeric Meraz and Eagle Young

This is a stick dance [shows image], I noticed the beautiful stick dance that Tane was doing yesterday and that's something that we also have, the planting with sticks. But in this dance the men are activating the knowledge of 'waffle' gardening, a form practiced in the desert, to be able to retain the rare water. So it's one of the joys when we get to see each other's work and noticing similarities and noticing the differences and being able to honor both.

So that is the landscape, the historical landscape that I was emerging out of, first in the ballet. I came from a very 
chaotic family life. So I wanted order I wanted discipline and that was what ballet and even traditional powwow dance was to me - very disciplined and formal. Ballet then led to modern dance and they were very separate worlds from the traditional Native dances. So for at least a decade they were held as very separate worlds. I wanted to try bringing those worlds together but it wasn't the time for it. I thought it would be a great idea to dance 'Dying Swan' on the reservation, and that it would be something that people would just love, you know [laughs].

And Grandma Geraldine said, "and what would you be wearing to dance", and then I recalled that back in those days - and I'm not that old - when attending a powwow I was asked to always wear a skirt to the ground and keep my arms covered. Very modest. So that doesn't make a typical ballet rehearsal outfit very acceptable [laughs]. So, I decided it wasn't a good idea, better to keep that part of my dance life separated.

Same thing with the mainstream dance world, the best idea at the time was, "let's do a Native River Dance" which just seemed like a bad idea to me, as it didn't reflect any respect for the complex cosmologies of a culture. So I just let the dance forms continue to be their own separate worlds. I danced at powwows, but in modern times there are now contest powwow where the best dancers win prizes and its changed powwows a lot and not all people feel that it's for the better. But I like to look for the positive and I see that its brought about a lot of creativity and innovation in the regalia, and high levels of dance skills. But I dance powwow in order to maintain good relations, and I already made a living from my other dance. So my dance would stay 'traditional'; I might still dance in a circle with the other women during the contest dances because that's when the really good honour songs for women are heard. And when the dance is done I simply leave the circle so the other women can line up for judging.

There is something that's called Hanbleceya, it's called 'crying for a vision' in which you are placed outside and then 
you don't eat or drink for at least four days in order to tune yourself to spirit. So I have my own version of Hanbleceya, it wasn't something that I asked for, I was diagnosed with stage 4 cancer about ten years ago and when I came out of it I was like an egg without a shell. Usually an egg has a nice shell that sort of protects us and I lost that shell, the things that made me feel like myself. My long braided hair - didn't have that anymore, I didn't have my muscles, most of the skin on my face was burned off. But what I had were the prayers of my friends from all over the world and I remember, when you're just at that edge, that, that place between worlds, being able to hear the spirits calling me out, calling out my name, seeing them in silhouettes and shadows in a circle. I thought oh maybe those are the ancestors coming to take me away, but instead there were people here on earth who were calling me back in and it brought me to my purpose. If I'm to be back on earth, back alive then what is it that I am going to give to the world that doesn't exist before now?

I knew that Indigenous contemporary dance would be the dream I would birth. I wasn't able to dance myself at that time, I could barely walk but I still needed to work, I needed to a job, I needed to pay my medical bills. So I sort of basically hobbled over to a meeting with a museum curator who said, Rulan if you can dance in two and a half months, I will get you one performance here at the museum and we will pay you a good amount of money so you can pay some of your medical bills. And I said, yes. I was thinking I better get a great costume and a great live musician so that I could sort of just drape myself pose by the paintings in the museum. I was hoping I could do that and so I said yes...

So I went to my first rehearsal with them and I thought it would just be just posing but instead it become so much more. All the funders that were sponsoring were invited to that first rehearsal so they could check it out. Basically, to see if I could do it. So I turned to the young violinist I had hired, who was very handsome by the way, and said that "here we go". 


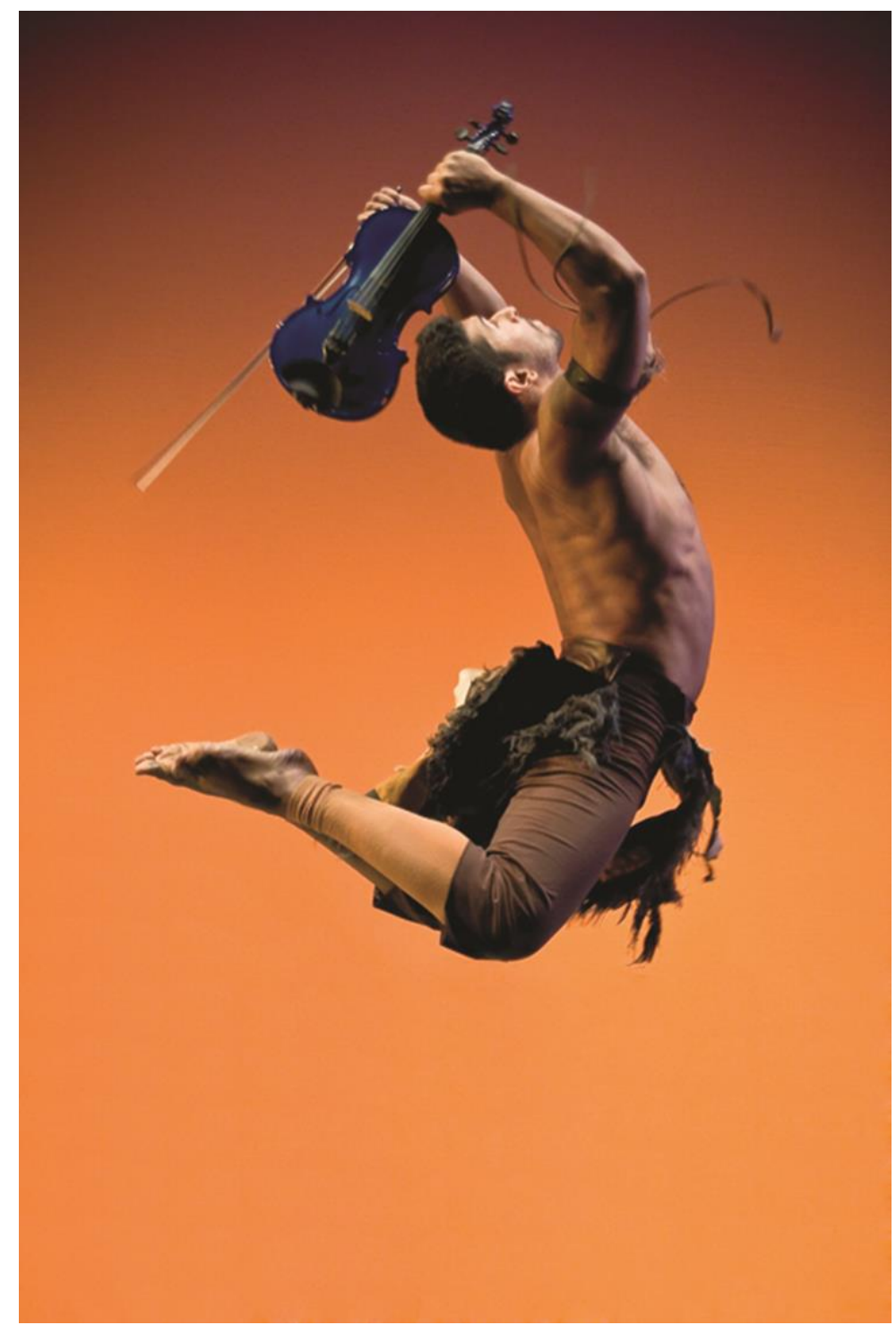

Photo: Paulo T Photography for Dancing Earth Pictured: Quetzal Guerrero

Te Kaharoa, vol. 8, SPECIAL EDITION, the Kowhiti Atarau collection, 2015, ISSN 1178-6035 
He lifted that violin and that sound that came out just lifted me, lifted my spirit. I started to improvise and it lasted 25 minutes, and I can barely do a solo that long now. But it was spirit leading the way and when I was done, the handsome young violinist who accompanied me said "hey, you know what, I'm a break dancer! I have native buddies that are break dancers too" and this trio was my first company, the beginning of what I am sharing today.

And that violinist Quetzal is here in Aotearoa on tour with me now, because he had planted his seeds for this dream as well, when he joined the company as a founding member.

That's why it means a lot for me. I feel that my ancestors were coming to beckon me back. So I mentioned all of these things, resistance, renewal, freedom, gender balance, feminine leadership, bridging the sacred with theatrical and these are the seeds of the garden.

But then if we do this, if we bring this into the world, we do it first for our native young ones to give them something, to feel strong about in their identity, to be able to model healthy living, strong bodies. Sometimes when I bring these dancers down to the reservation there is a lot of shock, "oh, I didn't know that people could look like that, they are like superheroes"! Many young Native people have been facing diabetes, health issues, depression, the most vulnerable in all statistics.

So we want to try to diminish that reality by putting a different reality forward. 


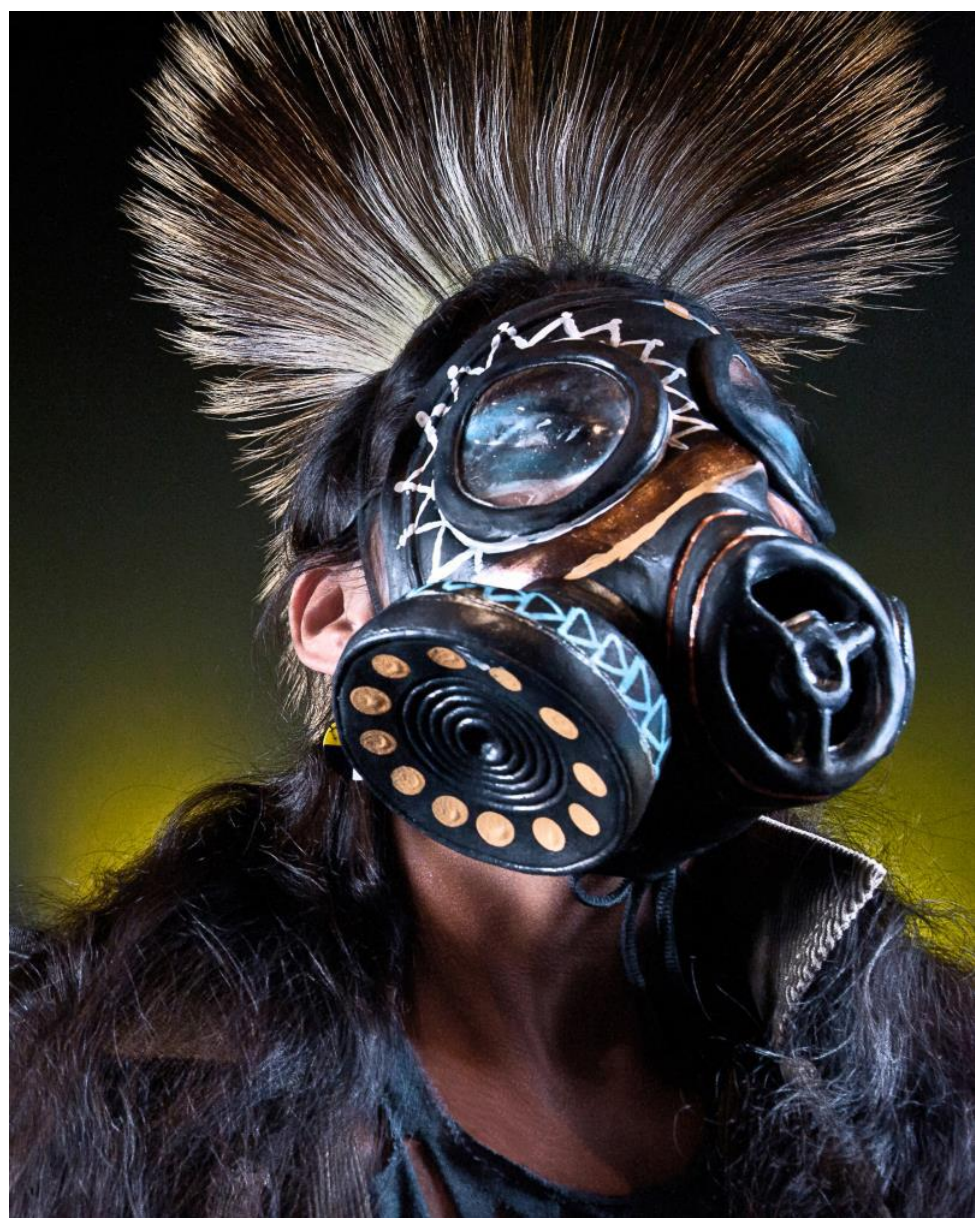

Photo: Paulo T Photography for Dancing Earth Pictured: Nimkii Osawameck

But when it came time a few years ago for us to start to do more sharing with the rest of the world the question is, "what is it that's appropriate to share? "

So those of you who are culture carriers you know that not everything is appropriate to share. Some of it is meant to stay close, just for people of that particular culture, or for young 
girls of that society, maybe this is for the children, or that for the elders. Some things need to be private, protected.

So in this case I went to elders and culture carriers to ask, "what is it that can be shared at this time", and actually the message was coming to me, little taps on my shoulder from grandmothers, at so many different places where I would go, the same message. Water. Different stories, all the same message. They said it's about healing the waters of our bodies and of our planet.

Prior to that I had been working on creating dances with a less explicit narrative form, embodying a story rather than telling it, using symbol and metaphor in movement. And I was making it happen, just pulling it out of, out of nowhere, just imagining it out of nothing, pulling out scraps and creating something new. There are costumes that are made out of discarded fabrics, and actual trash. I was being creative with whatever I had. And eventually, a 'green' eco-movement started coming into consciousness with a new way of framing this: "this is sustainability". Oh yes, this IS sustainability and all the stories we share are about relationships, about ecology. So that's what our dances are about, and it's also how we make our dances, by doing things in an environmentally conscious way.

So we are coming from the desert, here to Aotearoa, carrying ecological concerns about water. 


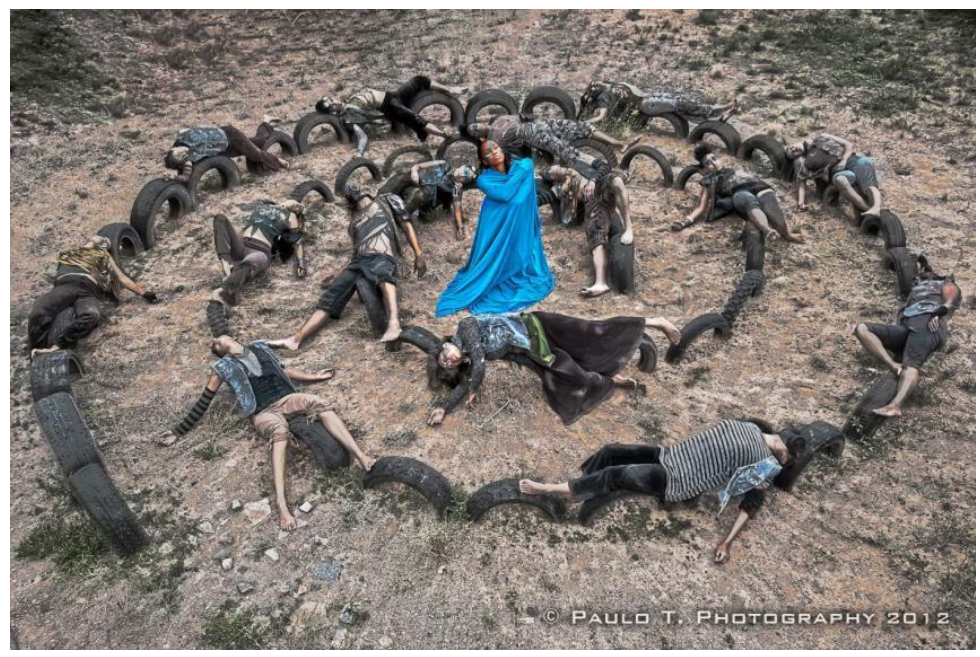

\section{Photo :Paulo T Photography for Dancing Earth Pictured Sina Soul and Dancing Earth Company}

This (image of a desert) is what it looks like for us. Very different from here.

But for many, many peoples of our lands, the water been dammed away to go to cities, it is being assaulted with uranium mining, and hydro fracking - which pumps chemicals into our water system in order to penetrate the deep layers of the earth to get oil. Water, the energy of life; fossil fuels are literally fossils, the blood of our ancestors, and it's the energy of death. (Note from Rulan: not long after this Festival, Tracey Marama Lloydd who was there with us at this lecture and festival, attended a rally against hydro fracking on the west coast of Aotearoa, and it was something she didn't know about before seeing this dance work).

It's causing lots of sickness in our lands, and so we are basically singing and dancing in these sacred creation stories of many of our peoples try to alter that reality.

I actually don't end with this photo, I am just going to end with this gratitude for what comes to us from you all as such 
loving people. We can just give you these gifts of our dance, and express our gratitude for the dance of life that you are sharing with as the people of Aotearoa - whether it's in words, whether it's in organising, whether it's the cooking, art work, and bringing art to life with your dances. So I wanted to invite you all to be able to feel the embodiment of what I've been talking about, to move in order to experience this. I spoke about the four directions and I just invite you in your seats [laughs] to be able to experience that yourself. So you put yourself in the centre of your circle and we reach to the front we reach into the future for our aspiration and our ambitions. But to balance that energy towards the future and what's ahead of us is the groundedness of what's behind us, our ancestors. So we reach behind us, stretching the spine, lifting the heart and lifting your face to the sky which is also our past in the creation stories that trace us back to stars. Supporting the back of your head and letting ourselves rest in the hands of our ancestors, then lift to return all the way back to centre. Then twisting your left side - the side of your heart, if everyone does that you're looking at the spine of the person next to you. Seeing that persons ancestors in their spine.

Then the other direction, to see the spine on the other side. These are the four directions that you can see when you see this symbol of a circle with four points. Our drawings often contain secret symbols, and in this case the circle is actually a multi-dimensional sphere. So in fact there are more than four directions indicated in this symbol. Fifth direction, reach up above to the sky, sixth direction down below the ground. Now our seventh direction you can make a circle of any kind, you go all around looking for that circle in that seventh direction and going in a circle always brings us back to our centre, back to our umbilical cord and connects that now to our spine where our ancestors are. So this is our seventh direction.

I just want to thank you. There is so much of global imagery about the USA - about Native Americans and African 
Americans, that really comes from Hollywood and media and isn't truthful representation that includes our voices .

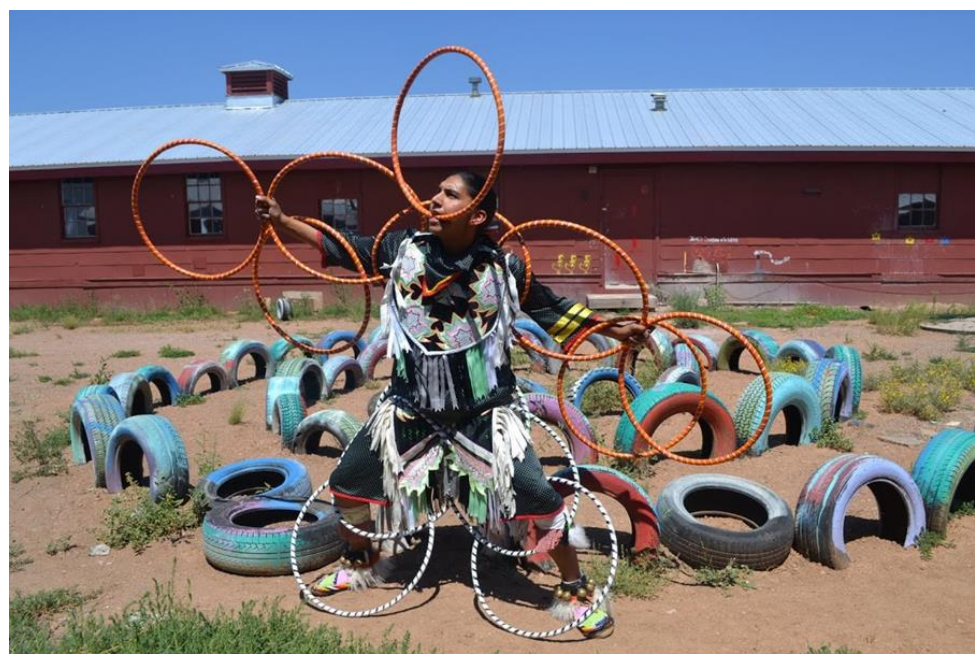

Photo: Alicia Ledezma for Dancing Earth Pictured: Nimkii Osawameck

So it is a great honor to be welcomed to share some history - relative to our form of Indigenous contemporary dance - by the people here, who stand so strongly in advocacy for your truth. It's really quite powerful that, for a change, that are voices are welcomed and heard.

When we are on tour we originally have just wanted to just let the dance speak, and do like other dance companies, just do our performance, and then, you know, get back on that tour bus. But what we found was that people were experiencing a truth that they had no idea existed, even just the way we looked, that we didn't look like Native people in the movies. And so they were shaken by the truth and they'd be mobbing us in the dressing rooms to ask questions, "how is it that you know how to speak English? ", and they weren't stupid people, they were disenfranchised by the educational 
system of the United States. They were influenced by the you know, the images that are made up by someone else, so it's absolutely true that we now have a responsibility to share our histories and our stories as culture carriers, as best as we can. For me it's a big challenge and I think of the elder who said, "in the absence of anyone else you must, you must do your part so here I am [laughs]".

Well let me put a question out to you. I've been saying what we bring with our bowl and with you as Maori people and as artists and supporters of the arts maybe we can pose a question: what are the important elements you are receiving from the bowl that we bring? "In reciprocity, and in gratitude for the chance to continue this weaving of global indigenous relations between our people, I say kia ora, pilomniya, nya:weh, mahalo, ch migwech and the many words and gestures of thank-you that will grow with us as our circles grow! 